\title{
Creating Segregation in the Era of Integration: School Consolidation and Local Control in New Brunswick, New Jersey, 1965-1976
}

\section{Chris Rasmussen}

New Brunswick High School, which had been racially integrated for decades, became majority-minority (and soon, all minority) in the 1970s, after years of legal wrangling led bundreds of its students to depart for a new, nearly allwhite high school in the adjacent suburb of North Brunswick. White suburbanites invoked "local control" to justify building their own high school and battled against both New Brunswick and the New Jersey Department of Education, which ostensibly supported integration and the creation of larger, consolidated school districts. Black and Latino city residents initially advocated integration but soon renounced integration and demanded "community control" over New Brunswick High. Ultimately, the New Jersey Department of Education permitted the schools in the city and the suburb to become separate, allowing segregation to prevail in the so-called "era of integration."

Americans battled fiercely over public schools during the "era of integration" that ensued after the US Supreme Court's 1954 ruling in Brown v. Board of Education. ${ }^{1}$ Many of these clashes-in Little Rock, Charlotte, Detroit, and Boston-gained nationwide attention and shaped historians' narratives of desegregation. A lesser-known controversy over school integration in New Brunswick, New Jersey, in the 1960s and 1970s complicates our understanding of the dynamics of racial politics and education policy in this era, and of the obstacles to school integration. New Brunswick, a small industrial city in central in New Jersey, confronted a host of problems in the 1960s and 1970s, including deindustrialization, suburbanization, and racial conflict. As

Chris Rasmussen is Associate Professor of History at Fairleigh Dickinson University, and author of "'A Web of Tension:' The 1967 Protests in New Brunswick, New Jersey," in the Journal of Urban History (2014). He wishes to thank HEQ editors Nancy Beadie and Joy Williamson-Lott, the journal's anonymous readers, and Jennifer M. Jones for their thoughtful suggestions.

${ }^{1}$ Paul Finkelman, The Era of Integration and Civil Rights, 1930-1990 (New York: Garland Publishing, 1992). 
the New York Times accurately observed in a report on New Brunswick's difficulties in 1972, "While many of the problems facing the city may eventually be solved, it is the problem of the schools that will continue to plague the community." ${ }^{2}$ New Brunswick High School, which had been racially integrated for decades, became the focal point of a protracted legal and political battle over issues of race relations, integration, "community control," school consolidation, and busing. Years of wrangling between New Brunswick and the adjacent suburb of North Brunswick exposed deep racial tensions, divided city against suburb, and pitted both against the state government. In 1974, the state of New Jersey permitted hundreds of white students to depart New Brunswick High to enroll in a new, virtually allwhite high school in North Brunswick, causing the city's formerly integrated high school to become majority-minority. Afterward, New Brunswick High's white enrollment dwindled until the school enrolled almost exclusively black and Latino students. As the era of integration drew to a close, schools in the two communities became separate and unequal.

An account of how segregation prevailed over integration in New Brunswick complicates our understanding of the dynamics of race relations and education in the 1960s and 1970s. As recent historical accounts of school desegregation have argued, integration was only one of many strategies that black Americans utilized to combat inequality in education. As Jack Dougherty observes in his study of the Milwaukee public schools, the debate over race relations and education was "more than one struggle," encompassing much more than an effort to desegregate public schools. ${ }^{3}$ Some black parents and students advocated integration and supported busing as a means to achieve racially integrated schools, but others opposed busing and doubted whether integration was attainable or even desirable. Dionne Danns explains in her study of the civil rights struggle in Chicago that whites' intransigence, coupled with the growing influence of black nationalism, led some black residents to reject desegregation and embrace community control of schools. ${ }^{4}$ Other historians have also observed that a growing number of black residents in many cities renounced integration and advocated community control over public education, demanding more influence over school boards

${ }^{2}$ Alfonso A. Narvaez, "New Brunswick: Its Ills Are Almost Manageable," New York Times, Nov. 24, 1972, 67.

${ }^{3}$ Jack Dougherty, More Than One Struggle: The Evolution of Black School Reform in Milwaukee (Chapel Hill: University of North Carolina Press, 2004), 3-4; see also 104-66.

${ }^{4}$ Dionne Danns, Something Better for Our Children: Black Organizing in Chicago Public Schools, 1963-1971 (New York: Routledge, 2003), 2, 61-88. 
and administrators, better education for black students, and the addition of black history and culture to curricula. ${ }^{5}$ Battles over community control roiled many districts, and the 1968 New York City teachers' strike, which pitted the United Federation of Teachers against the community-controlled, majority-black schools in the city's Ocean Hill-Brownsville neighborhood, gained nationwide attention, publicizing the stark differences separating black residents from teachers and school administrators, a majority of whom were white. ${ }^{6}$

Examining the decade-long battle over integration in New Brunswick also adds to our understanding of the ways in which structures of political and economic power at both the local and state level shaped the process of school integration and resistance to it. Ansley Erickson's influential recent study of school desegregation in Nashville, for example, elucidates the possibilities and limits of the era of integration by considering the ways in which debates over public education were deeply connected to the city's political economy. Erickson offers a nuanced explanation of the ways in which the city's Board of Education ostensibly sought to implement desegregation but ultimately remade segregation and inequality in three distinct ways: First, in collaboration with city planners and real estate developers, the board drew school boundaries with an eye toward improving some neighborhoods, while neglecting others. Second, schools offered different and unequal curricula to black and white students, steering black students to study vocational subjects to prepare them for their designated role as workers in the city's growing economy. Finally, Erickson perceptively notes that residents created narratives about "de facto segregation" and "white flight" that explained the persistence of segregation as a product of citizens" choices and obscured the role of political decision-makers and economic interests in maintaining inequality.

${ }^{5}$ For examples of these arguments see: Alan B. Anderson and George W. Pickering, Confronting the Color Line: The Broken Promise of the Civil Rights Movement (Athens: University of Georgia Press, 1986); James R. Ralph, Northern Protest: Martin Luther King, Jr., Chicago, and the Civil Rights Movement (Cambridge, MA: Harvard University Press, 1993); Daniel Perlstein, Justice, Justice: School Politics and the Eclipse of Liberalism (New York: Peter Lang, 2004), 114-26; and Matthew Countryman, Up South: Civil Rights and Black Power in Philadelphia (Philadelphia: University of Pennsylvania Press, 2006), 223-57.

${ }^{6}$ For an account of the 1968 New York teachers' strike, see Jerald E. Podair, The Strike That Changed New York: Blacks, Whites, and the Ocean Hill-Brownsville Crisis (New Haven, CT: Yale University Press, 2002). Heather Lewis argues that community control of schools contributed to real improvements in minority students' education. Heather Lewis, New York City Public Schools from Brownsville to Bloomberg: Community Control and Its Legacy (New York: Teachers College Press, 2013).

${ }^{7}$ Ansley T. Erickson, Making the Unequal Metropolis: School Desegregation and Its Limits (Chicago: University of Chicago Press, 2016), 11-18. 
An examination of the struggle over public education in New Brunswick draws upon the insights of recent scholarship on desegregation, which emphasizes the importance of community control, political power, and economic interests. Yet the history of race relations and public schools in New Brunswick differs in key respects from many other cities' experience. The city's high school had been integrated for decades, although most of its elementary schools were racially imbalanced. The city's demographics had not been remade by white flight, and whites remained a majority of the city's residents throughout the 1960s and 1970s. Hundreds of local white students attended parochial or private high schools instead of New Brunswick High. ${ }^{8}$ Still, whites remained a majority of New Brunswick High's students (79 percent in 1968, declining to 60 percent in 1973) because the nearby, nearly all-white communities of North Brunswick and Milltown, which did not have high schools of their own, participated in a regionalized school district that bused students to New Brunswick in an arrangement known as a sending-receiving relationship. ${ }^{9}$ Tensions over race relations in the public schools grew in the $1960 \mathrm{~s}$ and exploded in 1969, when residents of North Brunswick, whose children had attended high school in New Brunswick for a century, invoked "local control" of education and voted to build their own high school. The creation of a suburban high school would siphon away approximately seven hundred white students from New Brunswick High, transforming it into a majority-black school. Many New Brunswick residents predicted that the suburban white students'

${ }^{8}$ The 1970 US Census lists 2,058 high school students in the city, 1,728 of whom attended New Brunswick High. All 726 black high school students were enrolled in New Brunswick High School, which suggests that 330 white students were enrolled in private and parochial high schools. US Census Bureau, 1970 Census of Population, Vol. 1, Section 1, Part 32: Characteristics of the Population, New Jersey (Washington, DC: Government Printing Office, 1973), Table 103, 32-450; Table 108, 32-496. For a history of parochial schools and relations between Catholics and blacks in Northern cities, see John T. McGreevy, Parish Boundaries: The Catholic Encounter with Race in the Twentieth-Century Urban North (Chicago: University of Chicago Press, 1996); Patrick D. Jones, The Selma of the North: Civil Rights Insurgency in Milwaukee (Cambridge, MA: Harvard University Press, 2009); and Gerald H. Gamm, Urban Exodus: Why the Jews Left Boston and the Catholics Stayed (Cambridge, MA: Harvard University Press, 1999).

${ }^{9}$ On the high school's composition, see Board of Education of the City of New Brunswick v. Board of Education of the Township of North Brunswick in New Jersey School Law Decisions (Trenton, NJ: Department of Education, n.d.), 962-68 (hereafter New Brunswick v. North Brunswick (1974)); and Board of Education of New Brunswick $v$. Board of Education of North Brunswick and Board of Education of Milltown (1974) in New Jersey School Law Decisions (Trenton, NJ: Department of Education, n.d.), 977-78 (hereafter New Brunswick v. North Brunswick and Milltown (1974)). 


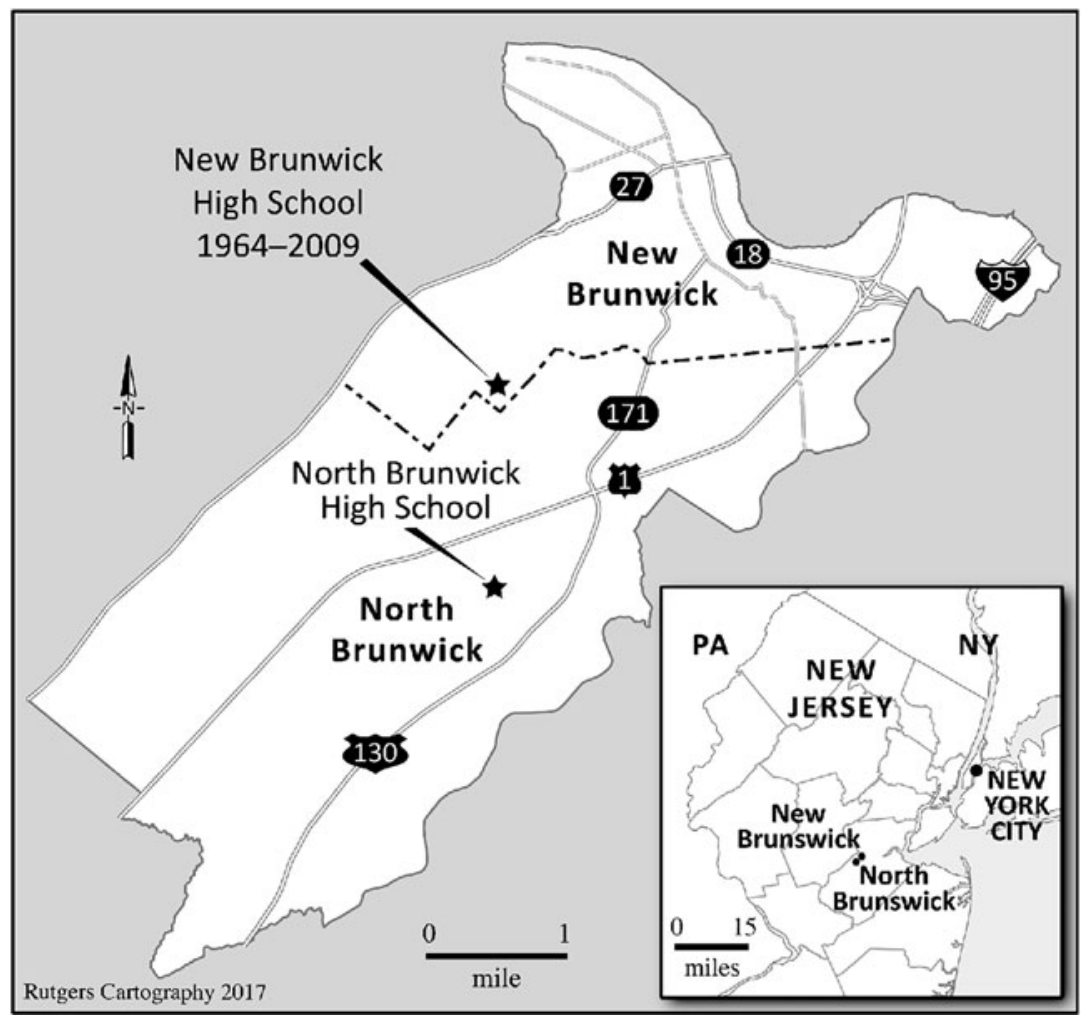

Figure 1. New Brunswick and North Brunswick, New Jersey (Rutgers Cartography, 2017)

departure would in turn lead white students from New Brunswick to leave the school as well.

Some white residents of New Brunswick and the city's Board of Education urged the state government to preserve racial integration in the city's schools and sought either to preserve the existing sendingreceiving relationship or to merge New Brunswick and North Brunswick into a consolidated school district. They argued that merging the districts and continuing to bus students between "the Brunswicks" offered the only means to maintain racially integrated schools and comply with the state Department of Education's policy of ensuring racial integration. While some white residents sincerely supported racial integration, many also worried that the city's economy, which had already declined as a result of deindustrialization and suburbanization, would suffer even more losses if the public schools became majority-minority. White residents of North 
Brunswick, on the other hand, often criticized racial trouble in New Brunswick High but also believed that creating a local high school would enhance their suburb's appeal, future growth, and housing values. Issues of race, real estate, and political economy were entwined in the debate over public schools in the Brunswicks. ${ }^{10}$

Members of New Brunswick's minority communities initially fought to preserve integration and resisted North Brunswick's effort to sever its relationship with the city's schools. ${ }^{11}$ But a growing number of blacks and Latinos soon renounced their support for integration and espoused community control as the best strategy for improving educational opportunities for minority students. Racial integration, they argued, did not entail racial equality or necessarily improve educational quality. Black and Latino parents and students complained that school administrators and teachers treated minority students unfairly, discouraging them from enrolling in college prep classes and shunting them into vocational courses. The school's faculty, administration, and the Board of Education contained few minority members. Black and Latino history and culture were absent from the curriculum.

\footnotetext{
${ }^{10}$ For excellent studies of how the relationship between suburban housing markets and school policy shaped one another, see Matthew D. Lassiter, "Schools and Housing in Metropolitan History: An Introduction," Journal of Urban History 38, no. 2 (March 2012), 195-204. Also in the same issue, see Jack Dougherty, "Shopping for Schools: How Public Education and Private Housing Shaped Suburban Connecticut," 205-24; Karen Benjamin, "Suburbanizing Jim Crow: The Impact of School Policy on Residential Segregation in Raleigh," 225-46; and Ansley T. Erickson, "Building Inequality: The Spatial Organization of Schooling in Nashville, Tennessee, after Brown," 247-70. Battles over race relations and public education were fought in many New Jersey school districts in the 1960s and 1970s, but some districts managed to work together cooperatively. In the southern part of the state, citizens created several large regional high schools to serve students from suburban areas. See William W. Cutler III and Catherine D'Ignazio, "Public Education: Suburbs," The Encyclopedia of Greater Philadelphia, http://philadelphiaencyclopedia. org/archive/public-education-suburbs/.

${ }^{11}$ On the civil rights movement in the North, see Thomas J. Sugrue, Sweet Land of Liberty: The Forgotten Struggle for Civil Rights in the North (New York: Random House, 2008); Sugrue, The Origins of the Urban Crisis: Race and Inequality in Postwar Detroit (Princeton, NJ: Princeton University Press, 1998), 5; and Jacquelyn Dowd Hall, "The Long Civil Rights Movement and the Political Uses of the Past," Journal of American History 91, no. 4 (March 2005), 1233-63. On racial segregation and blacks' resistance to it, see Arnold R. Hirsch, Making the Second Ghetto: Race and Housing in Chicago, 1940-1960 (New York: Cambridge University Press, 1983); Kenneth T. Jackson, Crabgrass Frontier: The Suburbanization of the United States (New York: Oxford University Press, 1985), 198-203, 287-90; and Martha Biondi, To Stand and Fight: The Struggle for Civil Rights in Postwar New York City (Cambridge, MA: Harvard University Press, 2003).
} 
The "battle of the Brunswicks" resulted in eighty-eight hearings before the state Board of Education, provoked repeated protests and troubles in New Brunswick's junior high and high school, and convulsed the city's politics. As the battle dragged on, local residents and New Jersey state officials created different narratives to explain their view of the struggle over race relations and public education. Black residents of New Brunswick recounted their struggle to wrest control over their local schools from an educational bureaucracy that espoused racially integrated schools but disserved black students. White suburbanites told a story of an urban high school engulfed in turmoil, which justified their demand to build a separate school. State education officials proclaimed their support for school integration and yet, step-by-step, permitted North Brunswick to build its own high school, claiming that they were effectively powerless to mandate integration in the face of sustained opposition from residents, white and black. Ultimately, these differing stories culminated in the same ironic ending: during the era of integration, a new, nearly allwhite high school opened in North Brunswick; New Brunswick's formerly integrated public high school became majority-minority; and, as some local residents had predicted, local white students' enrollment declined until the school enrolled only minority students. In short, education in the Brunswicks became separate and unequal.

\section{Hub City and Garden State}

New Brunswick, which billed itself as central New Jersey's bustling "Hub City," confronted political and racial upheaval, suburbanization, and economic decline in the 1960s and 1970s. The black population in New Brunswick grew steadily throughout the twentieth century. In 1960, blacks made up 15.4 percent of the city's population. In 1970, that percentage had risen to 22.7 percent; in 1980, it was 28.5 percent. Latinos, principally Puerto Ricans, were 3.5 percent of the city's population in 1970. Meanwhile, the white population declined from 84.2 percent in 1960 , to 75.9 percent in 1970 , and then to 63.1 percent in $1980 .{ }^{12}$ According to one estimate, the city lost five thousand jobs in these decades, as factories closed and stores moved to suburban shopping centers. The city's poverty rate was 14.4 percent in 1970, but 19.9 percent for blacks and 26.6 percent

${ }^{12}$ US Census Bureau, County and City Data Book, 1967 (Washington, DC: Government Printing Office, 1967), 524; US Census Bureau, 1970 Census of Population, Table 108, 32-496; Table 16, 32-53; and US Census Bureau, 1980 Census of Population, Vol. 1, Part 32: New Jersey (Washington, DC: Government Printing Office, 1982), Table 14, 32-11; Table 15, 32-20. 
for Puerto Ricans. ${ }^{13}$ As businesses and some white residents moved to suburbia, the economy and tax base of the "Hub City" declined. ${ }^{14}$

New Brunswick's public schools had been integrated since the 1880 s, and they remained integrated into the 1970s. On the other hand, as Davison Douglas notes, segregated schools were common in New Jersey and in the North. The state of New Jersey began to address the problem of school segregation before the federal government. The New Jersey Supreme Court declared racially segregated schools unconstitutional in its 1944 ruling in the Trenton case of Hedgepeth v. Board of Education of Trenton; three years later, an amendment to the state constitution prohibited segregated schools. ${ }^{15}$ In 1954, the US Supreme Court's Brown ruling declared segregated public schools "inherently unequal," and the following year, the Court stipulated that desegregation proceed with "all deliberate speed."16 While Brown and the ensuing civil rights movement pointed toward racial integration, suburbanization forestalled racial equality by creating and reinforcing de facto segregation. ${ }^{17}$ As many whites moved to the suburbs, blacks and Latinos remained concentrated in New Jersey's cities. The subtitle of Walter Greason's book states bluntly that "the suburbs ended the civil rights movement in New Jersey." ${ }^{8}$ But New

${ }^{13}$ US Census Bureau, 1970 Census of Population, Table 33, 32-179; Table 107, 32490; Table 111, 32-508; Table 112, 32-512.

${ }^{14}$ New Brunswick Tomorrow, Downtown Development District Urban Renewal Plan: New Brunswick, New Jersey (prepared by Mayers \& Schiff, Architects/Planners), Special Collections and University Archive Rutgers University Libraries, New Brunswick, NJ.; and Edward C. Burks, "Urban Sprawl Transforms the Face of Middlesex," New York Times, April 16, 1972, 88.

${ }^{15}$ Davison M. Douglas, Jim Crow Moves North: The Battle Over Northern School Segregation, 1865-1954 (New York: Cambridge University Press, 2005), 2-5; Hedgepeth v. Board of Education of Trenton 131 NJL 153 (1944); and Sugrue, Sweet Land of Liberty, 175-79.

${ }^{16}$ Brown v. Board of Education, 347 U.S. 495 (1954); and Brown v. Board of Education, 349 U.S. 301 (1955).

${ }^{17}$ On racial inequality in the North and opposition to it, see Sugrue, Sweet Land of Liberty; on suburbanization and race relations in New Jersey, see Walter David Greason, Suburban Erasure: How the Suburbs Ended the Civil Rights Movement in New Jersey (Madison, NJ: Fairleigh Dickinson University Press, 2013); and Robert W. Lake, The New Suburbanites: Race and Housing in the Suburbs (New Brunswick, NJ: Transaction Publishers, 1981). For accounts of the battle over school integration in Teaneck, New Jersey, see Reginald G. Damerell, Triumph in a White Suburb: The Dramatic Story of Teaneck, N.J., the First Town in the Nation to Vote for Integrated Schools (New York: William Morrow, 1968); and Mike Kelly, Color Lines: The Troubled Dreams of Racial Harmony in an American Town (New York: William Morrow, 1995).

${ }^{18}$ Greason, Suburban Erasure. David Freund's detailed analysis of racial politics in Detroit reveals the ways in which many whites rejected racial integration in the 1960 s and began to identify suburbs and property ownership with whiteness. David 
Brunswick's schools were not remade simply by an inexorable process of suburbanization, "white flight," or de facto residential segregation, but by a complex and contentious debate over racial integration in public education and by a series of decisions in which policymakers allowed segregation to prevail.

The issues of race, public schools, and suburbs versus cities roiled New Jersey politics in the 1960s and 1970s, as the state government attempted to ensure school integration. ${ }^{19}$ The New Jersey Supreme Court ruled in Booker v. Board of Education of Plainfield (1965) that the state commissioner of education possessed broad authority to redress de facto as well as de jure segregation. ${ }^{20}$ In 1967, Commissioner of Education Carl Marburger, an ardent proponent of racial integration, determined that many of New Jersey's school districts should be consolidated into single districts in order to create larger, more efficient districts and to comply with the federal government's mandate to integrate public education. To achieve racial balance within these larger districts, Marburger advocated busing, a proposal that provoked a firestorm in New Jersey, as it did in many states and cities. Marburger's support for consolidating school districts was not prompted solely by his concerns about integration. State Department of Education officials believed that New Jersey had too many school districts, many of which lacked high schools of their own. Larger districts and larger schools, they insisted, were more efficient and offered students a more comprehensive education. The Department of Education made its most emphatic case for creating regionalized and consolidated school districts in its well-publicized and controversial 1969 report (the "Mancuso Report"), which declared that reorganizing and consolidating school districts and granting the state government a larger role in funding public schools were "necessary for eliminating educational deficiencies in New Jersey." Acknowledging that local communities would balk at consolidation, the report urged that the state government exercise its power to "mandate" the creation of larger school districts. $^{21}$

M. P. Freund, Colored Property: State Policy and White Racial Politics in Suburban America (Chicago: University of Chicago Press, 2010), 6-20, 328-99.

${ }^{19}$ Barbara G. Salmore and Stephen A. Salmore, New Jersey Politics and Government: The Suburbs Come of Age, 4th ed. (New Brunswick, NJ: Rutgers University Press, 2013), 313-18.

${ }^{20}$ Booker v. Board of Education of the City of Plainfield, 45 N.J. 161 (1965).

${ }^{21}$ New Jersey Department of Education, Report of the State Committee to Study the Next Steps of Regionalization and Consolidation in the School Districts of New Jersey (Trenton, NJ: Department of Education, April 1969), 10, 95. This was generally known as the Mancuso Report for committee chair Ruth H. Mancuso. 
The prospect of enforced regionalization, consolidation, and busing led opponents to push back against the state's authority and to assert local control over public education, making public schools a central issue in the political struggle between cities, suburbs, and the state government at a moment when suburban voters were gaining the upper hand in New Jersey politics. The New York Times reported that the 1967 campaign for the state legislature (New Jersey holds elections in odd-numbered years) "was dominated by the Republican charge that the Democratic administration of Governor Richard J. Hughes planned to bus white children from the suburbs to the cities to achieve racial integration in the schools," even though both political parties strongly opposed Marburger's proposal to consolidate school districts. On election day, Republicans turned a 2-to-1 Democratic majority into a 3-to-1 GOP advantage in the New Jersey Senate and Assembly.22

Racial discrimination and blacks' protest against it also reshaped politics in New Jersey and New Brunswick in the 1960s and 1970s. In July 1967, blacks' determination to fight against inequality erupted into six days of protest in Newark - an upheaval that left twenty-six people dead and protests spreading to several New Jersey cities. ${ }^{23}$ In the wake of the Newark unrest, black youths in New Brunswick, twenty-five miles to the south, voiced their anger at public school officials, unemployment, and lack of recreational opportunities. Black students and parents contended that the schools gave black students an inferior education and were quick to suspend or expel students for any infraction of school rules. As one black teenager put it, administrators could and would "use any excuse to get rid of us." 24 On July 17, hundreds of black youths took to the streets in New Brunswick, where they were confronted by over 150 police officers. The protesters vandalized and looted several businesses, but a full-scale riot did not break out. The following night, two hundred protesters engaged in a tense standoff with police and then confronted Mayor Patricia Sheehan, who mollified the crowd by vowing to improve race relations in the city. New Brunswick teetered on the brink of violence in 1967, yet did not slip over that brink. The Kerner Commission, appointed by

${ }^{22}$ Ronald Sullivan, "Hughes Defends Chief of Schools," New York Times, Oct. 18, 1967, 31; Sullivan, "Busing of Pupils a Top Jersey Issue," New York Times, Oct. 29, 1967, 72; and Sullivan, "A Hughes Setback," New York Times, Nov. 8, 1967, 1. On resistance to busing by blacks as well as whites, see Matthew Delmont, Why Busing Failed: Race, Media, and the National Resistance to School Desegregation (Oakland: University of California Press, 2016), 168-89.

${ }^{23}$ Hirsch, Making the Second Ghetto, xvi.

24 "Urban League Picnic Provides Cool Forum on Hot Topic," (New Brunswick, NJ) Daily Home News, July 23, 1967, 43. 
President Lyndon Johnson to study the urban protests of 1967, praised New Brunswick officials for averting conflict instead of escalating it. ${ }^{25}$ Although a potential explosion was defused in 1967, racial and economic problems continued to trouble New Brunswick throughout the 1970s, and local officials and residents worried that even a minor incident could touch off violence. ${ }^{26}$ After the city's underlying racial tensions were laid bare in 1967, the combination of poisoned race relations, suburbanization, deindustrialization, and declining tax revenues placed enormous strain on the city and its school system through the late 1960 s and 1970s.

\section{We Are Not Going to Beg}

After the 1967 protests, blacks in New Brunswick pressed Mayor Sheehan to improve race relations and insisted that the public schools become more responsive to black students. Board of Education meetings, previously sleepy affairs, became agitated, as black parents and students espoused the rhetoric of community control and demanded more say over the city's public schools. In November 1967, Rev. Edward L. Warner, chairman of the New Brunswick Human Rights Commission, asked the board to add black history to the schools' curriculum so that every black student would be "given the knowledge and values of what he is and what he stands for." 27 Black students embraced black nationalism more readily than did their elders in the 1960s, and they played a key role in pressing for change in New Brunswick's schools. ${ }^{28}$ In May 1968, Learline Jackson, a member of the New Brunswick Urban League's Youth Council, addressed the school board to urge the teaching of black history and better treatment

${ }^{25}$ Chris Rasmussen, “'A Web of Tension': The 1967 Protests in New Brunswick, New Jersey," Journal of Urban History 40, no. 1 (Jan. 2014), 137-57; and National Advisory Commission on Civil Disorders, Report of the National Advisory Commission on Civil Disorders (Washington, DC: Government Printing Office, 1968), 82-84.

${ }^{26}$ Melvin Goldstein, interview with Patricia Sheehan, Jan. 24, 1968, 3, National Commission on Civil Disorders records, series 59, box 5, LBJ Presidential Library, Austin, Texas.

${ }^{27}$ Minutes, Nov. 7, 1967, New Brunswick Board of Education, Archives, New Brunswick Public Schools, New Brunswick, NJ.

${ }^{28}$ Vincent Willis, “'Let me in, I have the right to be here': Black Youth Struggle for Equal Education and Full Citizenship after the Brown Decision, 1954-1969," Citizenship Teaching \& Learning 9, no. 1 (Dec. 2013), 53-70; Jon Hale, “'The Fight Was Instilled In Us': High School Activism and the Civil Rights Movement in Charleston," South Carolina Historical Magazine 114, No. 1 (Jan. 2013), 4-28; and Dara Walker, "We Were Fighting for Self-Determination and Power: Black High School Student Activism and the Black Power Movement" (Honors thesis, Eastern Michigan University, 2009). 
of black students. The board agreed to add black history to the curriculum in the fall, and board president Edward Lipman vowed, "If there is racism in our faculty, we are going to nail it." ${ }^{29}$ In June, David Harris, president of the New Brunswick Urban League, demanded that the board create a black advisory committee. When Theresa Schrum, president of the high school PTA, objected, saying "all you say is "we demand," Harris replied, "White people will have to get used to us saying "we demand.' We are not going to beg." ${ }^{30}$ The board voted to create a twenty-eight-member Community Advisory Committee made up of representatives of several black and Latino organizations. ${ }^{31}$ In December, high school student Kelly Jones blasted the board, accusing the schools of causing many black and Puerto Rican students to drop out. Jones urged the high school to hire more black teachers (it had only one) because "we come from different environments and most of these white teachers are not equipped to relate to us." 32

The assassination of Rev. Martin Luther King Jr. in April 1968 provoked protests at Rutgers University and New Brunswick High. Rutgers enrolled few black students, and King's murder led many students to demand that the university increase its number of minority students and faculty members. ${ }^{33}$ Black students at New Brunswick High, upset that the public schools remained open during King's funeral, walked out of school in protest, and vandals smashed downtown store windows and hurled rocks at passing cars in one of the city's black neighborhoods. Rutgers president Mason Welch Gross helped defuse racial tension on campus and in the city by announcing that the university would begin enrolling more disadvantaged black students from Newark, Camden, and New Brunswick. Rutgers's commitment to diversifying its student body quelled protest, but hardly resolved the underlying problems in the city or its schools. ${ }^{34}$

${ }^{29}$ Minutes, May 7, 1968, New Brunswick Board of Education; see also Minutes, June 4, 1968, New Brunswick Board of Education.

${ }^{30}$ Minutes, June 4, 1968, New Brunswick Board of Education.

${ }^{31}$ Minutes, Aug. 6, 1968, New Brunswick Board of Education. The committee included representatives from the Urban League, NAACP, Black Unity Organization, Black Steering Committee, New Brunswick Soul Force, Neighborhood House, Puerto Rican Family Social Club, Latin American Social Organization, and Puerto Ricans in the U.S.

${ }^{32}$ Minutes, Dec. 3, 1968, New Brunswick Board of Education.

${ }^{33}$ Richard P. McCormick, The Black Student Protest Movement at Rutgers (New Brunswick, NJ: Rutgers University Press, 1990), 23-30.

34 "Negro Students Demonstrate," (New Brunswick, NJ) Daily Home News, April 5, 1968, 1; "Rutgers Attacked on Racial Role," (New Brunswick, NJ) Daily Home News, April 6, 1968, 1; "Negro Students Stage Walkout at High School," (New Brunswick, NJ) Daily Home News, April 8, 1968, 1; Steven Alexander and Tony Gioe, "King's Death Sparks Attack on 'White Racism' at Univ.," Rutgers Targum, April 8, 1968, 1; 


\section{A Full-Scale Riot}

In March 1969, simmering racial issues in New Brunswick boiled over on the Rutgers campus, in town, and in the schools. In early March, Rutgers students accused the university of failing to implement the reforms promised in 1968, and demanded that more black students be admitted and that African American history and culture be added to the curriculum. ${ }^{35}$ Protest on campus spilled over into town, as students and residents argued bitterly about local government, the police, and the schools. A group of white residents founded Concerned and Responsible Citizens (CRC) to oppose blacks' calls for change in New Brunswick. The CRC criticized Mayor Sheehan's oversight of the police force and the schools, and presented her with a list of ten demands, titled "P.O.W.E.R.", which stood for "Protection of White Equal Rights." The CRC demanded that the mayor impose a curfew, opposed her decision to create a civilian review board to examine allegations of police misconduct, and insisted that she grant the CRC veto authority over the hiring of police officers. According to the local newspaper, the Home News, Mayor Sheehan "appeared shaken" by the vehemence of the CRC members. ${ }^{36}$ On March 13, upwards of a thousand white residents packed a CRC meeting at the Hungarian American Athletic Club, where, the newspaper reported, "Most speakers called for action against Negroes they claim have made the city's streets and schools unsafe." Mayor Sheehan did not attend the meeting but sent a statement of her views, which the audience booed. ${ }^{37}$ Patrolman Jesse Biczi warned that America was being "overtaken from within," and declared that he had "never met a good American Negro." Police Chief Ralph Petrone suspended Biczi for his remarks, and the city's eight black police officers resigned, stating that they would not serve alongside Biczi. ${ }^{38}$ Vincent DiPane, a former police officer and harsh critic of Mayor Sheehan's

Lenny Kinland and Tony Mauro, "Speakers at Friday Night Teach-in Rip University Support of Racism," Rutgers Targum, April 8, 1968, 1; Harvey Fisher, "More Than 1,000 Rally Against Racism," (New Brunswick, NJ) Daily Home News, April 9, 1968, 1; "Vandals Strike as Tense City Waits, Hopes," (New Brunswick, NJ) Daily Home News, April 10, 1968, 1; Learline Jackson, et al., letter to the editor, "The High School Walkout," (New Brunswick, NJ) Daily Home News, April 11, 1968, 5.

${ }^{35}$ McCormick, Black Student Protest Movement, 46-55.

${ }^{36}$ Harvey Fisher, "Citizens' Group Presents Demands," (New Brunswick, NJ) Daily Home News, March 14, 1969, 1.

${ }^{37}$ Reginald Kavanaugh, "CRC Wants City to Meet Demands," (New Brunswick, NJ) Daily Home News, March 17, 1969, 1.

38 "Chief Suspends Officer," (New Brunswick, NJ) Daily Home News, March 14, 1969, 1; "8 Black Policemen Resign in Protest," (New Brunswick, NJ) Daily Home News, March 15, 1967, 1; "City PBA Supports Ptl. Biczi," (New Brunswick, NJ) Daily Home News, March 15,1969, 12; and "Biczi Apologizes for Statement," (New Brunswick, NJ) Daily Home News, March 17, 1969, 17. 
handling of the 1967 protest, organized a petition to recall the mayor and the entire City Commission, accusing them of failing "to protect the citizens and their property." 39

Tensions at Rutgers and in the city reverberated through the halls of New Brunswick High and Junior High, and black and white students boycotted school and scuffled repeatedly. Black students accused school administrators of discrimination and claimed that the Board of Education was concerned only with retaining white students, rather than improving the quality of education. White students charged that the schools had become unsafe. On March 18, black and white students met separately at New Brunswick Junior High to discuss racial issues in the school. The school exploded in "a full-scale riot" when approximately one hundred black students disrupted the white students' meeting, hurling dishes and chairs, breaking windows, causing an estimated $\$ 4,000$ in damage, and injuring several students, teachers, police officers, and passersby. ${ }^{40}$ Black and white students at New Brunswick High also engaged in a series of protests, fights, and acts of vandalism. The school board ordered both schools closed temporarily in response to racial strife that, according to the New York Times, "has all but paralyzed the educational process." 41

At an acrimonious meeting of the City Commission the day after the melee in the junior high, Mayor Sheehan declared, "We have got to work out how we are going to live in this community, black and white-it's not going to be black versus white, and it can't be young

39 “Citizens' Group Presents Demands," (New Brunswick, NJ) Daily Home News, March 14, 1969, 1; advertisement for Recall Petition, (New Brunswick, NJ) Daily Home News, March 16, 1969, 2; and Reginald Kavanaugh, "CRC Wants City to Meet Demands," (New Brunswick, NJ) Daily Home News, March 17, 1969, 1.

${ }^{40}$ For a report on the riot at the junior high, see Minutes, April 1, 1969, New Brunswick Board of Education. The total damage was $\$ 3,959.50$. See Minutes, May 5, 1969, New Brunswick Board of Education. See also George Dawson and Alvin King, "Junior High Students, Police Scuffle," New Brunswick, NJ) Daily Home News, March 18, 1969, 1.

${ }^{41}$ George Dawson, "Scuffle Breaks Calm at New Brunswick High," (New Brunswick, NJ) Daily Home News, March 14, 1969, 1; "Weekend of Meetings Set to Calm Schools," (New Brunswick, NJ) Daily Home News, March 15, 1969, 1; Ted Serrill and Frank Kelly, "Police, Faculty Prevent Fracas at High School," (New Brunswick, NJ) Daily Home News, March 17, 1969, 1; Frank Kelly, "Exodus Begins in Senior High; Few Students Stay in Class," (New Brunswick, NJ) Daily Home News, March 18, 1969, 1; Richard J. H. Johnston, "Jersey School Reopens," New York Times, March 18, 1969, 31; Johnston, "Blacks Rampage in Jersey School," New York Times, March 19, 1969, 34; George Dawson, "Tension-Easing Steps Taken as Three City Schools Close," (New Brunswick, NJ) Daily Home News, March 19, 1969, 1; and Richard J. H. Johnston, "New Brunswick Presses Search for a School Peace Formula," New York Times, March 20, 1969, 31. 
versus old." ${ }^{42}$ While local officials, educators, and parents met to discuss the turmoil in the schools, Neighborhood House, a meeting place for black citizens and organizations, sustained arson damage, prompting widespread suspicion that "the Nabe" had been set ablaze in retaliation against blacks' expression of their grievances. ${ }^{43}$

After more than a week of upheaval, an uneasy calm returned to the public schools, if not to the city. On March 21, two thousand high school students, black and white, staged a "walk-out/walk-in," singing as they marched out of school arm in arm, then returned to class in a demonstration of racial harmony. Senior class president Louis Marchetto proclaimed that the students had "unified the school and the community" by proving that blacks and whites wanted to be educated together. ${ }^{44}$ Adults in New Brunswick were less hopeful. Some three hundred CRC supporters met that evening to endorse a recall vote against Mayor Sheehan, and one member, Mike De Salvo, ominously threatened to retaliate against protesters by spilling "blood in the city." 45

\section{The Battle of the Brunswicks}

The remainder of the school year passed without serious incident, and the Board of Education agreed to "integrate" the curriculum by adding more black and Latino history. ${ }^{46}$ When classes began in September 1969, however, fights broke out between black and white students, and some two hundred whites refused to attend school until they received assurance that school officials would protect them from what they termed "black terrorism." 47 On September 29, more than

42 "City Begins Searching Its Soul," (New Brunswick, NJ) Daily Home News, March 19, 1969, 1; and Richard J. H. Johnston, "New Brunswick Presses Search for a School Peace Formula," New York Times, March 20, 1969, 31.

43 “'Suspicious' Fire Damages Neighborhood House," (New Brunswick, NJ) Daily Home News, March 19, 1969, 1; John Pribish and William Heffernan, "Neighborhood Arson Probe Begins," (New Brunswick, NJ) Daily Home News, March 19, 1969, 1

${ }^{44}$ George Dawson, "City Students March in Fellowship," (New Brunswick, NJ) Daily Home News, March 21, 1969, 1; Harvey Fisher, "CCA to Seek Better City," (New Brunswick, NJ) Daily Home News, March 22, 1969, 1; Barbara Selick, "CRC Backs Recall Petition," (New Brunswick, NJ) Daily Home News, March 22, 1969, 1; Richard J. H. Johnston, "New Brunswick Students Link Arms in Show of Racial Amity," New York Times, March 22, 1969, 1; and "N.B.H.S Happening," Advocate, New Brunswick High School Yearbook, 1969, n.p.

${ }^{45}$ Barbara Selick, "CRC Backs Recall Petition," (New Brunswick, NJ) Daily Home News, March 22, 1969, 1.

${ }^{46}$ Minutes, May 5, 1969, New Brunswick Board of Education.

${ }^{47}$ Richard J. H. Johnston, "210 Students Strike New Brunswick High," New York Times, Sept. 30, 1969, 34. 
two hundred high school students, both black and white, stayed home to protest the turmoil in the school. Amid these protests, superintendent of schools Morris Epps ordered the schools closed because the district's insurance policy had expired and, owing to the high probability of vandalism and violence, no insurer would underwrite the schools. Mayor Sheehan and Governor Hughes intervened, persuading the insurer to renew the schools' policy so the schools could remain open. ${ }^{48}$

Racial tensions in New Brunswick led residents in the adjacent town of North Brunswick, a nearly all-white community that bused its students to New Brunswick High, to launch plans in 1969 to build a local high school and middle school. North Brunswick's population had grown from 10,099 in 1960 to 16,691 in 1970. Nearly 98 percent of the town's residents were white. While North Brunswick was not affluent, it was significantly wealthier than New Brunswick, where one-fifth of black residents were impoverished. ${ }^{49}$ In October, the North Brunswick Board of Education voted unanimously to initiate the formal process to create a local high school and passed a resolution complaining that sending districts had no voice in the policies of receiving schools, calling this arrangement nothing less than "taxation without representation." The Board of Education of nearby Milltown, an all-white community that bused students to New Brunswick High, also voted to send students to North Brunswick High when it opened. ${ }^{50}$ To justify their decision for building their own high school and defying the state government's effort to compel them to participate in a regionalized or consolidated school district, North Brunswick residents invoked "local control" over education. New Jersey, with its nearly six hundred localities and more than six hundred school districts, has a deeply entrenched tradition of "home rule" or "local

48 "New Brunswick Shuts Schools," New York Times, Sept. 24, 1969, 41; "210 Students Picket," (New Brunswick, NJ) Daily Home News, Sept. 29, 1969, 1; Richard J. H. Johnston, "210 Students Strike New Brunswick High," New York Times, Sept. 30, 1969, 34; Harvey Fisher, "High School Protesters Quit Marching," (New Brunswick, NJ) Daily Home News, Sept. 30, 1969, 1; and "City Tells Educators: Do Job or Leave," (New Brunswick, NJ) Daily Home News, Sept. 30, 1969, 1. On the schools' insurance policy, see Minutes, Oct. 7, 1969, New Brunswick Board of Education; and Minutes, Nov. 4, 1969, New Brunswick Board of Education.

${ }^{49}$ US Census Bureau, 1970 Census of Population, Table 33, 32-179. For a comparison of the income levels of the communities' residents, see Urban League of Greater New Brunswick v. Carteret (1976), in American Land Planning Law: Cases and Materials, vol. 2, ed. Norman Williams Jr. (New Brunswick, NJ: Transaction Publishers, 2012), 1050-51.

${ }^{50}$ Minutes, Oct. 14, 1969, North Brunswick Board of Education, Archives, North Brunswick Township Public Schools, North Brunswick, NJ. 
control"- as Governor Brendan Byrne observed in the 1970s, "home rule is a religion in New Jersey." 51

North Brunswick's decision to create its own high school and withdraw its students from New Brunswick High collided with the New Brunswick school board's effort to maintain its racially integrated high school and the New Jersey Department of Education's goal of ensuring integration in public education. In November, the Board of Education and the Commissioner issued a mandate, requiring school districts to devise plans to remedy racially-imbalanced schools. ${ }^{52}$ The department permitted the North Brunswick board to continue planning its new high school only on the condition that the school's opening would not result in racially segregated schools in the Brunswicks. North Brunswick's determination to build its own school, though, almost invariably ran counter to the state's goal of racial integration.

The state's mandate on desegregation had implications not only for New Brunswick High but also for the city's elementary schools. Although New Brunswick's high school and junior high were integrated, five of its eight elementary schools were attended overwhelmingly by white or by minority students (Table 1). Because North Brunswick operated its own elementary schools, it did not bus elementary students to New Brunswick. ${ }^{53}$

As Andrew Highsmith and Ansley Erickson point out, school segregation did not result solely from residential segregation. Local governments and real estate developers often promoted and enforced racially segregated neighborhoods, but school officials also sought to create "community schools," which would serve as cultural hubs for neighborhood residents, and drew school district boundaries to create racially homogenous schools. The New Brunswick school board considered the racial makeup of the city's elementary schools when drawing school boundaries. ${ }^{54}$

In February 1970, the New Brunswick school board, declaring that it would "make every effort to bring about a better balance among the races," unanimously resolved to comply with the state's

${ }^{51}$ Salmore and Salmore, New Jersey Politics and Government, 239-40, 309-18; 239.

${ }^{52}$ New Jersey State Board of Education, Minutes, Nov. 5, 1969, State Board of Education papers, New Jersey State Archives, Trenton, NJ, Box SZEDU 004; and State Board of Education, Annual Report of State Board of Education and Commissioner of Education to the Legislature of the State Legislature of New Jersey, 1969-1970 (Trenton: Department of Education, 1970), 5-6.

${ }^{53}$ Statistics from Minutes, Feb. 3, 1970, New Brunswick Board of Education; and Minutes, April 7, 1970, New Brunswick Board of Education.

${ }^{54}$ Andrew R. Highsmith and Ansley T. Erickson, "Segregation as Splitting, Segregation as Joining: Schools, Housing, and the Many Modes of Jim Crow," American Journal of Education 121, no. 4 (Aug. 2015), 563-95. 
Table 1. Racial and ethnic composition of New Brunswick elementary schools, 1970

\begin{tabular}{lccc}
\hline School Name & Percent White & Percent Black & $\begin{array}{c}\text { Percent Other } \\
\text { (principally Puerto Rican) }\end{array}$ \\
\hline Bayard & 5 & 49 & 46 \\
Lincoln & 60 & 34 & 5 \\
Livingston & 49 & 37 & 13 \\
Lord Stirling & 7 & 78 & 13 \\
McKinley & 14 & 84 & 1.6 \\
Nathan Hale & 5 & 84 & 11 \\
Washington & 61 & 35 & 4 \\
Wilson & 95 & 3.5 & 1.5 \\
\hline
\end{tabular}

Source: Minutes, Feb. 3, 1970, New Brunswick Board of Education; and Minutes, April 7, 1970, New Brunswick Board of Education.

Mandate on Desegregation..$^{55}$ "If the law says integrate, we must integrate," board president Edward Lipman stated the following month, as the board allocated $\$ 100,000$ for busing in its budget for the 1970-1971 school year. ${ }^{56}$ Plans to bus elementary school students upset many white residents. Mrs. Henry Hartmann, president of the Woodrow Wilson Elementary School PTA, objected to busing, stating that educational and counseling programs could more effectively improve race relations (95 percent of Wilson students were white). ${ }^{57}$ Several black residents and educators, however, supported integration. Louis Diggs, president of the Nathan Hale Elementary School PTA, and Henry Daniels, principal of Lord Stirling Elementary School, favored busing (95 percent of Hale School students and 91 percent of Stirling students were black or Latino). "If the students are going to live together," Diggs stated, "we must integrate the schools." 58

The New Brunswick Board of Education strove to integrate its elementary schools, to prevent the construction of a high school in North Brunswick, and to merge the Brunswicks into a single school district, but the city's soured race relations accelerated the growth of suburbs, the construction of suburban schools, and de facto segregation. The board argued that the creation of a high school in North Brunswick would violate the federal and state governments'

\footnotetext{
${ }^{55}$ Minutes, Feb. 3, 1969, New Brunswick Board of Education.

${ }^{56}$ Minutes, Jan. 29, 1969, New Brunswick Board of Education.

${ }^{57}$ Ibid.

${ }^{58}$ Minutes, Feb. 3, 1969, New Brunswick Board of Education.
} 
commitment to integration: New Brunswick High would become a majority-black school, while 96 percent of North Brunswick High students would be white. An exodus of North Brunswick students might also cause many white parents in New Brunswick to withdraw their children from the high school, and would deprive New Brunswick High of the more than $\$ 700,000$ in tuition paid by North Brunswick residents. For all these reasons, board president Eli Saltz vowed in May 1970 to "do everything possible to have North Brunswick stay."59

The following month, North Brunswick voters passed by nearly two-to-one a $\$ 9.8$ million bond issue to construct a local junior high and high school. Residents of North Brunswick were eager to have their own school and stop paying tuition to send their children to New Brunswick High. The high school had also become overcrowded, forcing the New Brunswick Board of Education to divide students into two sessions beginning in the fall of 1970. As the Home News reported, though, North Brunswick voters supported the bond principally because of the "racial disorder that has plagued the city school." 60

In July 1970, black youths in New Brunswick took to the streets on three consecutive nights to protest race relations in the city. The protest erupted after the city government canceled a dance scheduled at Memorial Homes, a low-income housing complex, citing violence that had ensued after a dance there the previous week. Youths gathered at Memorial Homes and at an office of the local antipoverty agency to discuss their frustrations: no jobs, poor housing, mistreatment by school administrators and the police, and a lack of recreational opportunities. Afterward, the youths marched into the business district, shouting "All power to the people!" and "Death to the pigs!" They smashed several store windows and set fire to Sapiro Auto Parts, which suffered serious damage. Mayor Sheehan responded by imposing a curfew, setting roadblocks along the highways into New Brunswick, and reinforcing the city's police force with officers from nearby communities. ${ }^{61}$

\footnotetext{
${ }^{59}$ Minutes, May 5, 1970, New Brunswick Board of Education.

${ }^{60}$ Voters approved the school bond by a vote of 2,119 to 1,135 . See Ruth Peterson Mihalenko, North Brunswick: A Township History (North Brunswick, NJ: North Brunswick Bicentennial Commission, 1977), 36-38; "State Gives Okay to New High School," (New Brunswick, NJ) Home News, June 10, 1970, 1; John Moore, "North Brunswick OKs School Bonds," (New Brunswick, NJ) Home News, June 25, 1970, 1; and Minutes, June 24, 1970, North Brunswick Board of Education. On overcrowding in New Brunswick High School, see Minutes, June 2, 1970, New Brunswick Board of Education.

${ }^{61}$ Gordon Sharp, "Youths Cause Downtown Ruckus," (New Brunswick, NJ) Home News, July 23, 1970, 22; "Inadequate Jobs, Housing, Recreation Seen as Causes," (New Brunswick, NJ) Home News, July 24, 1970, 19; William Heffernan, "Why Are Young
} 
Mayor Sheehan, facing a tough reelection campaign in 1970, was far less conciliatory to the protesters than she had been three years earlier. In 1967, the mayor listened patiently as black teenagers vented their grievances; now, she accused them of committing "vicious mischief" and declared that violence and disorder "will not be tolerated." 62 Black residents considered the protest a response to the mayor's failure to improve race relations in the city. The Black Voice, a student newspaper at Rutgers University, dismissed Sheehan's claim that a few rabble-rousers were needlessly stirring up trouble as "a damn and vicious lie," declaring that "the people" were rising up against discrimination. ${ }^{63}$ A local alternative newspaper, All You Can Eat, accused Sheehan of using the protest "as an excuse for continued police harassment of the black and Puerto Rican community" and to aid her reelection bid by appealing to the city's white majority. ${ }^{64}$ Political considerations undoubtedly impelled Sheehan to take a tougher stance in 1970 than she had in 1967. Rival candidate Ralph Muehlig's "Save Our City" platform promised to restore "law and order" in New Brunswick, and the mayor's most strident white opponents reviled her as the "African Queen" for negotiating with black protesters in $1967 .{ }^{65}$ In November, Sheehan won reelection, defeating Muehlig by a margin of five hundred votes out of nearly ten thousand cast. ${ }^{66}$

Blacks Shouting in Anger?," (New Brunswick, NJ) Home News, July 24, 1970, 1; "Fire Bombs Hurled in Business Area of New Brunswick," New York Times, July 25, 1970, 36; and Richard J. H. Johnston, "New Brunswick Orders Curfew," New York Times, July 25, 1970, 15.

${ }^{62}$ Alvin King and Gordon Sharp, "Deplore Vicious Mischief," (New Brunswick, NJ) Home News, July 24, 1970, 1; and "Seize the Time," Black Voice Newsletter 1, no. 6 (July 1970), 1. Special Collections and University Archives, Rutgers University Libraries, New Brunswick, NJ. The Black Voice Newsletter was begun as a newsletter representing black students at Rutgers University in 1969. It merged with the Carta Boricua in 1974.

63 "Seize the Time"; and "On the New Brunswick Riot," Black Voice Nerwsletter 1, no. 7 (Aug. 1970), 2.

64"Town Official Tells Where It's At," (New Brunswick, NJ) All You Can Eat, Aug. 17, 1970, 4; Ken Mandell, "Riot On," (New Brunswick, NJ) All You Can Eat, Aug. 17, 1970, 5; and Captain Marvell, "At the Zoo," (New Brunswick, NJ) All You Can Eat, Aug. 17, 1970, 5 .

${ }^{65}$ David Harris, interview with author, July 14, 2010; "New Brunswick: Its Ills Are Almost Manageable;" and "We Endorse Sheehan Slate," (New Brunswick, NJ) Home Nerws, Oct. 29, 1970, 30.

${ }^{66}$ Sheehan defeated Muehlig 5,202 votes to 4,701 votes. John Pribish, "Mayor Sheehan Squeezes Out Victory," (New Brunswick, NJ) Home News, Nov. 4, 1970, 1. 


\section{Busing and Consolidation: "The people are absolutely against it."}

Busing generated sharp opposition nationally, in New Jersey, and in New Brunswick. In April 1971, the US Supreme Court's landmark ruling in Swann v. Charlotte-Mecklenburg Board of Education upheld the constitutionality of busing as a means to implement school desegregation. ${ }^{67}$ But Swann proved a Pyrrhic victory for supporters of integration, provoking a furious backlash against busing from many whites. Consolidating the Brunswicks into a single school district and busing students offered a feasible means to attain racial integration. The two communities were adjacent, and the proposed North Brunswick High School lay only 2.6 miles from New Brunswick High by roadway, while the physical distance between the schools was only 1.5 miles. (New Brunswick's high school building, opened in 1964, was located near the boundary with North Brunswick to encourage the suburb's residents to continue sending their children to the high school.) Two months after the Swann decision, the New Jersey Supreme Court ruled in Jenkins v. Township of Morris School District that the commissioner of education possessed the authority to mandate sending-receiving relationships or regionalization of school districts if these measures were "necessary for fulfillment of the State's educational and desegregation policies." ${ }^{8}$ The Department of Education temporarily restrained the North Brunswick Board of Education from proceeding with the bid process for building a high school, relenting only after the board promised to "work actively" with the New Brunswick board to assure that the school would not result in racial segregation. ${ }^{69}$

Despite this promise not to create segregated schools, residents of North Brunswick fought to prevent the state Department of Education from merging the communities' school districts and busing students to achieve integration. In October 1971, the North Brunswick Board of Education unanimously passed a resolution endorsing local control and opposing the state's authority to consolidate or regionalize school

${ }^{67}$ Swann v. Charlotte-Mecklenburg Board of Education, 402 U.S. 1 (1970).

${ }^{68}$ Jenkins v. Township of Morris School District, 58 N.J. 483 (1971) in New Jersey School Law Decisions (Trenton, NJ: State Board of Education, n.d.), 507. The New Jersey Supreme Court issued its ruling on June 25, 1971. See also Jenkins v. Township of Morris School District (1970) in New Jersey School Law Decisions, (Trenton: State Board of Education, n.d.), 389-415; and Jenkins v. Township of Morris School District (1971) in New Jersey School Law Decisions (Trenton, NJ: Department of Education, $n$. d.), 688-705.

${ }^{69}$ The history of these rulings is summarized in New Brunswick v. North Brunswick (1974), 962-68. See also Minutes, Sept. 21, 1971, New Brunswick Board of Education; and Minutes, Oct. 19, 1971, New Brunswick Board of Education. 
districts unless local residents voted to approve the merger. ${ }^{70} \mathrm{New}$ Brunswick Board of Education president Saltz accused North Brunswick of reneging on its promise to cooperate with New Brunswick, stating that the suburb's residents were "not sincerely interested" in integration. ${ }^{71}$ Battles over integration and busing in the Brunswicks, as elsewhere, were not solely about race, but also about class. As both Gary Orfield and Ronald P. Formisano point out, many working-class and lower-middle-class whites felt that more affluent Americans and policymakers were imposing school desegregation on them. ${ }^{72}$ North Brunswick was wealthier than New Brunswick, but it was hardly affluent. Nearly a third of its residents had low or moderate incomes, and most parents had little choice but to enroll their children in the local public schools, including New Brunswick High. ${ }^{73}$ Although North Brunswick had bused students to New Brunswick High School for years, when the New Jersey commissioner of education proposed busing as a means to preserve integrated high schools in the Brunswicks, many North Brunswick residents complained that the state was foisting integrated schools on them.

Crucially, many black and Latino students and parents in New Brunswick also turned against busing and regionalization to endorse community control of public education, but for reasons different from white residents of North Brunswick. They recognized that North Brunswick residents were determined to build their own high school and that many white residents of New Brunswick would likely refuse to send their children to a majority-minority high school if the North Brunswick students withdrew. Embracing the ideas of black and Latino nationalism, they renounced their support for integration and for merging their high school with North Brunswick's and declared that their paramount goal was to improve the education for minority students in the local public schools. They appropriated New Jersey's tradition of local control and began to advocate for community control

${ }^{70}$ Minutes, Oct. 12, 1971, North Brunswick Board of Education. The board passed a similar resolution in 1972. Minutes, Feb. 12, 1972, North Brunswick Board of Education.

${ }^{71}$ Minutes, Oct. 19, 1971, New Brunswick Board of Education.

${ }^{72}$ Gary Orfield, Must We Bus?: Segregation and National Policy (Washington, DC: Brookings Institution, 1978), 407; Ronald P. Formisano, Boston Against Busing: Race, Class, and Ethnicity in the 1960s and 1970s (Chapel Hill: University of North Carolina Press, 1991), 220-21, 231-33; and J. Anthony Lukas, Common Ground: A Turbulent Decade in the Lives of Three American Families (New York: Alfred A. Knopf, 1985).

${ }^{73}$ Statistics on the income of North Brunswick residents are cited in Urban League of Greater New Brunswick v. Mayor and Council of the Borough of Carteret, 142 N.J. Super. 11 (1976), 1050-51. 
of the city's public schools. ${ }^{74}$ For blacks and Latinos, community control meant adding black and Latino history to the curriculum, hiring more black and Latino teachers, and adding more minority members to the Board of Education, whose members were appointed by the mayor. From 1966 to 1970 , the board had a lone black member; from 1971 through 1973 it had two, but whites remained a majority. Instead of petitioning the state government to preserve integration, minority parents and students now sought to make the schools' curriculum and personnel more responsive to minority students.

In October 1971, black and Puerto Rican students staged a walkout from New Brunswick High to protest the school's insensitivity to their concerns. The students called the walkout in response to an issue that looms large in the high school pecking order: black students complained that only one of the school's eighteen cheerleaders was black. When school officials agreed to hold tryouts for a new cheer squad, a fight erupted between white and black students. According to the Black Voice, police officers assaulted and arrested black students but did not intervene against white students. After this incident, black and Puerto Rican students boycotted classes. A few days later, they attended the New Brunswick Board of Education meeting to present their list of twenty "demands," which included dismissing Principal William Lindstrom; hiring more black and Puerto Rican teachers, counselors, and security guards; adding classes in black and Puerto Rican history; enrolling more minority students in college prep courses; and appointing more minority members to the board. The board rejected the students' demands and refused to negotiate with them until they returned to classes. ${ }^{75}$ Black and Puerto Rican parents, organizations, and ministers supported the students' protest, as did the Black Voice, which accused the school board of seeking to maintain the school's appeal to white residents, rather than serving the needs of minority students. White residents, according to the paper, worried that an exodus of students to North Brunswick High would cause New Brunswick High to hit "the 'tipping point,' when the school's population becomes so Black and Puerto Rican that whites leave the community." Black and Puerto Rican parents charged that school administrators catered to the

\footnotetext{
${ }^{74}$ On the battle over school integration in New Jersey prior to Brown, see Sugrue, Sweet Land of Liberty, 175-79; on the consequences of Brown, see 181-99; on community control, see 471-77.

75 “Venceremos !” Black Voice Newsletter 3, no. 7 (Oct. 1971), 2; "How It Happened," Black Voice Newsletter 3, no. 7, Oct. 1971, 4; "What We Want," Black Voice Newsletter 3, no. 7, Oct. 1971, 7; and Minutes, Oct. 19, 1971, New Brunswick Board of Education. The account in the Black Voice lists twenty demands; the Board of Education minutes lists eighteen.
} 
interests of white students and residents and subjected minority students to unfair treatment and an inferior education. ${ }^{76}$

Troubles between black and white students repeatedly disrupted New Brunswick High in the spring of 1972. On March 1, a fight broke out, resulting in the suspension of seventeen students. On March 7, many North Brunswick parents kept their children out of New Brunswick High, charging that the school could not ensure students' safety. ${ }^{77}$ After more fights broke out in April, the North Brunswick Board of Education declared the high school unsafe, recommended that North Brunswick parents keep their children home from school, and prohibited school buses from transporting students to New Brunswick. ${ }^{78}$ The North Brunswick Chamber of Commerce also encouraged parents and students to boycott New Brunswick High, and urged the North Brunswick Board of Education to withhold tuition payment for the sending-receiving relationship with New Brunswick. $^{79}$

Suburbanization and racial tensions were accelerating demographic change in New Brunswick and its schools, as white enrollment in the city's junior high and high school declined in the early 1970s. In 1968, 79 percent of the high school's students were white; by 1973, that figure had slipped to 60 percent. ${ }^{80}$ White parents in North Brunswick and Milltown were also withdrawing their children from New Brunswick High: in 1966, 90 percent of North Brunswick students and 86 percent of Milltown students attended New Brunswick High. When the school year began in 1972, those figures had shrunk to 66 and 26 percent. $^{81}$

76 “Emergency Community Meeting," Black Voice Newsletter 3, no. 7 (Oct. 1971), 7.

${ }^{77}$ Minutes, March 7, 1972, North Brunswick Board of Education; and Juan Johnson, "Future of New Brunswick High School Students Argued in Trenton," Black Voice, March 1972, 1. On March 19, only days after the hearing in Trenton, Neighborhood House was damaged by arson for the second time in three years. Barbara Selick, "Pre-Dawn Fire of Suspicious Origin Damages the Neighborhood House," (New Brunswick, NJ) Home News, March 20, 1972, 17.

78 "17 Arrested In City Fights," (New Brunswick, NJ) Home News, April 25, 1972, 1; Minutes, April 25, 1972, North Brunswick Board of Education; and Jack Lutton, "North Brunswick Refuses to Bus Students to NBHS," (New Brunswick, NJ) Home News, April 26, 1972, 49.

${ }^{79}$ Letter from North Brunswick Chamber of Commerce to North Brunswick Board of Education, in Minutes, April 25, 1972, North Brunswick Board of Education.

${ }^{80}$ Thirty-four percent of students from New Brunswick were white; 96 percent of North Brunswick students were white; 100 percent of students from Milltown were white. See New Brunswick v. North Brunswick (1974), 977-78. On busing, see Orfield, Must We Bus?, 48-61.

${ }^{81}$ New Brunswick v. North Brunswick and Milltown (1974) 978. 
Rather than resist declining white enrollment, black residents of New Brunswick, like whites in North Brunswick, organized to oppose regionalization and consolidation, and advocated for local control. Residents organized the Black Home and School Organization (BHSO), which declared that good schools were more important than racial integration. ${ }^{82}$ In May 1972, Rev. W. Emanuel Barrett of the Ebenezer Baptist Church denounced regionalization, informing the board that "the people are absolutely against it." Charles Gray, assistant director of the local chapter of the Urban League, declared that "regionalization is not in the best interest of the people." ${ }^{33}$ The following month, the Greater New Brunswick Clergy Association submitted a petition to the board declaring that regionalization or consolidation "would be a serious backward step in terms of human relations in our community" and "should be dropped immediately." ${ }^{4}$

Both the New Brunswick Board of Education and the state government remained committed to consolidation and integration. In 1972, the New Brunswick Board of Education hired Charles Durant, a black man, as superintendent. Board members hoped that the new superintendent would help defuse racial tensions in the community, but his appointment seemed only to worsen them. Durant's staunch support for continuing the relationship between the New Brunswick and North Brunswick schools antagonized many blacks, and he endured outright racism from some whites. Durant moved into a middle-class white neighborhood, where he and his family confronted repeated slurs and harassment. ${ }^{85}$

The New Jersey Department of Education's commitment to school integration and consolidation provoked opposition in the Brunswicks and many other communities across the state. In June 1972, Republican governor William Cahill stunned New Jerseyans by nominating Carl Marburger, champion of integration, regionalization, consolidation, and busing, for another term as commissioner of education. The controversial nominee inflamed an already heated debate over the state's authority versus local control of schools, and the New Jersey Senate rejected his reappointment - a first in the state's history. As the New York Times observed, senators' opposition to

${ }^{82}$ Johnson, "Future of New Brunswick High School Students Argued in Trenton."

${ }^{83}$ Minutes, May 16, 1972, New Brunswick Board of Education.

${ }^{84}$ Greater New Brunswick Clergy Association petition, in Minutes, June 27, 1972, North Brunswick Board of Education.

${ }^{85}$ On Durant's support for regionalization, see Superintendent's Report, Dec. 1972, in Minutes, Dec. 19, 1972, New Brunswick Board of Education. 
Marburger stemmed from "an emotional reaction against the racially charged issue of school busing." 86

The tide of public opinion had turned decisively against consolidation and busing, and blacks in New Brunswick had become outspoken critics of the New Brunswick Board of Education. The BHSO not only opposed regionalization, but urged the board to rethink the fundamental mission of the city's schools. In the spring of 1973, the BHSO complained that the board was still waging a futile effort to keep white students enrolled in New Brunswick's schools, even though the school district "has been completely abandoned by whites." Meanwhile, "the public school system has failed miserably in their attempt to achieve their educational goals for these [black and Latino] students." The BHSO insisted that the Board of Education "must have the empowerment of the impoverished black and Puerto Rican community at the core of their school goals." 87 BHSO president Sandra Willis accused the board of supporting regionalization to enhance its own power and relegating black students' education to "second place." ${ }^{8}$

In April 1973, the New Jersey Supreme Court intervened in the debate over public education, issuing its landmark decision in Robinson v. Cabill, which ruled that wide disparity in expenditures per student between urban and suburban school districts violated the state constitution's guarantee of a "thorough and efficient system of free public schools." 89 Because public schools' funding derived principally from local property taxes, suburban schools had considerably more resources than urban schools, whose revenues had shrunk along with

${ }^{86}$ Ronald Sullivan, "Cahill Asks Jersey Legislators to Vote on Income Tax Bill First," New York Times, June 15, 1972, 34; Wolfgang Saxon, “Teachers' Group Wants Marburger Out," New York Times, Nov. 3, 1972, 69; Ronald Sullivan, "Jersey Rejects Education Chief," New York Times, Nov. 17, 1972, 1, 32; Lawrence Van Gelder, "Rejected Educator: Carl Louis Marburger," New York Times, Nov. 17, 1972, 32; and Ronald Sullivan, "Marburger Aftermath," New York Times, Nov. 18, 1972, 65.

${ }^{87}$ Minutes, Nov. 21, 1972, New Brunswick Board of Education. In response to pressure from the BHSO, the board agreed to hire educational consultants to study blacks' and Latinos' dissatisfaction with the public schools and to recommend strategies for improving education for minority students. Charles Durant, Superintendent's Report, Nov. 1972, in Minutes, Nov. 21, 1972, New Brunswick Board of Education.

${ }^{88}$ Minutes, March 20, 1973, New Brunswick Board of Education; Minutes, April 17, 1973, New Brunswick Board of Education; and Minutes, May 15, 1973, New Brunswick Board of Education. See especially Willis's statement at the meeting of May 15. Several black students were suspended for protesting against racial inequality in the high school. Minutes, Jan. 16, 1973, New Brunswick Board of Education.

${ }^{89}$ New Jersey State Constitution, Art. VIII, sec. IV., para. 1. This amendment to the state constitution was adopted in 1875 . 
cities' population and tax base. ${ }^{90}$ The court's decision seemed to necessitate an increase in state aid for urban school districts, potentially offsetting the decline in revenue that would result if the state allowed students from North Brunswick to leave New Brunswick High School.

When the new North Brunswick middle and high school building opened to grades seven through nine in September 1973, residents petitioned the New Jersey Department of Education to permit tenth graders to move immediately from New Brunswick High to the new facility (juniors and seniors were slated to complete their education at New Brunswick High). ${ }^{91}$ The New York Times reported the bitter controversy on page one: "School Showdown Looms in New Brunswick Dispute." The New Brunswick Board of Education opposed allowing North Brunswick's tenth graders to leave New Brunswick High, leading North Brunswick superintendent Arthur Wise to reply caustically, "What they're doing to their own people is an educational abortion." 92 The Citizens' Action Group, an organization of North Brunswick parents, defended "the right of a community to control the education of its children" and urged parents to stop sending their children to New Brunswick High. ${ }^{93}$ Three busloads of North Brunswick parents, who dubbed themselves Citizens for Quality Education, traveled to the state capital in Trenton to deliver a petition, signed by two thousand residents, urging the commissioner of education to allow sophomores to attend North Brunswick High. To dramatize their cause, North Brunswick parents organized a one-day boycott of New Brunswick High in September. The following month the North Brunswick Board of Education, citing a "dangerous atmosphere" and overcrowding in New Brunswick High (built to accommodate 1,469 students, the school enrolled 1,879), again prohibited buses from transporting students to New Brunswick High. ${ }^{94}$ The North Brunswick board

${ }^{90}$ Robinson v. Cahill 62 N.J. 473 (1973); and Deborah Yaffe, Other People's Children: The Battle for Justice and Equality in New Jersey's Schools (New Brunswick, NJ: Rutgers University Press, 2007).

${ }^{91}$ Board of Education of New Brunswick v. Board of Education of North Brunswick (1973) in New Jersey School Law Decisions (Trenton, NJ: Department of Education, n.d.), 579-80.

${ }^{92}$ Richard J. H. Johnston, "School Showdown Looms in New Brunswick Dispute," New York Times, Sept. 17, 1973, 1. Wise made his reference to abortion only months after the US Supreme Court's ruling in Roe v. Wade (1973).

${ }^{93}$ George Corrado, Citizens' Action Group, Minutes, North Brunswick Board of Education, Sept. 4, 1973.

${ }^{94}$ Richard J. H. Johnston, "Two Districts Are Hit by Protest," New York Times, Sept. 13, 1973, 98; Johnston, "School Showdown Looms in New Brunswick Dispute," New York Times, Sept. 17, 1973, 69; Bonny Levy, "North Brunswick School Row Heats with Protest, Boycott," (New Brunswick, NJ) Home News, Sept. 21, 1973, 1; Johnston, "North Brunswick Boycotts Schools," New York Times, Sept. 22, 1973, 68; Levy, "Figures Tell the Tale: Boycott Slashed Attendance," (New 
unanimously passed a resolution charging that New Brunswick had reneged on the districts' 1971 agreement to cooperate in maintaining racial integration and alleging that its members had signed the agreement only "under duress" because they feared that Commissioner Marburger would otherwise deny them authorization to plan and construct a new high school. ${ }^{95}$

The New Brunswick Board of Education continued to urge the New Jersey Department of Education to prevent North Brunswick from removing its students from New Brunswick High. It conceded that the New Brunswick schools had experienced racial troubles but pointed out that similar problems had occurred in many cities. Creating separate high schools for white and black students, it informed the State Board of Education, offered no solution: "a separation will deprive both groups of students of the advantage inherent in a fully integrated educational experience." ${ }^{16}$ In October 1973, Robert Greenwood, the Department of Education official responsible for examining the dispute between the Brunswicks, recommended that the department approve the transfer of North Brunswick's tenth graders out of New Brunswick High and that North Brunswick High accept some black students from New Brunswick in order to preserve a measure of racial integration. North Brunswick residents hailed Greenwood's recommendation, but New Brunswick school administrators castigated it as a step backward for racial equality. ${ }^{97} \mathrm{New}$ Brunswick High principal Donald Banchik blasted the proposed departure of the students and took a swipe at their parents, warning that "these students will receive an insulated, isolated education irrelevant to what's really happening in the world around them today. And when these kids eventually become parents themselves their perspective will be as narrow and prejudicial as their own parents' today." 98

Black residents of New Brunswick, however, advocated community control and opposed busing black students to North Brunswick to create racial diversity in the suburban high school. Only days after Greenwood issued his recommendations, BHSO members picketed

Brunswick, NJ) Home News, Sept. 22, 1973, 1; Jermaine Elkins, "North Brunswick Citizens Vow More Boycotts If Plan Fails," (New Brunswick, NJ) Home News, Sept. 23, 1973, A2; Johnston, "North Brunswick Presses for Transfer of Students," New York Times, Sept. 26, 1973, 87; and "Fear Expressed on School Ruling: New Brunswick Transfers Held State Precedent," New York Times, Oct. 11, 1973, 94.

${ }^{95}$ Minutes, Dec. 4, 1973, North Brunswick Board of Education.

${ }^{96}$ New Brunswick v. North Brunswick (1973), 580.

${ }^{97}$ New Brunswick v. North Brunswick (1973), 579-83; and Donald Janson, "Arbiter Backs Transfers at New Brunswick High," New York Times, Oct. 10, 1973, 51; and "Fear Expressed on School Ruling."

98 "Fear Expressed on School Ruling." 
the offices of the New Brunswick Public Schools, and nearly all of the high school's eight hundred black students boycotted classes. ${ }^{99}$ At the Board of Education's monthly meeting, David Harris, BHSO member and former president of the New Brunswick Urban League, accused the board of being concerned principally with maintaining white enrollment. Harris stated that he had no objection to the white students' departure from New Brunswick High but warned minority residents that the city's white majority would balk at paying taxes to support the public schools if most of their students were blacks and Latinos. As a result, racial minorities "would be dependent on a hostile majority population for the necessary resources to educate its [their] children." 100 While black residents advocated community control, they foresaw that whites' support for the schools would likely decline if the schools became majority-minority. ${ }^{101}$

The battle between the Brunswicks had become a focal point of New Jerseyans' response to changing race relations, urban decline, and suburbanization, and emerged as a major issue in the 1973 gubernatorial campaign, even though both the Republican and Democratic parties opposed busing. Republican candidate Charles Sandman kicked off his campaign by accusing Democratic rival Brendan Byrne of favoring consolidation and busing, proclaiming, "Home rule is a sacred thing in New Jersey. Those school districts that don't want to be consolidated don't have to be." Byrne also supported home rule and opposed busing. ${ }^{102}$ In order to declare their opposition to busing, both candidates attended the dedication ceremony for North Brunswick High School on October 28, only days before the election. ${ }^{103}$

${ }^{99}$ Richard J. H. Johnston, "Blacks Plan Boycott Today of New Brunswick School," New York Times, Oct. 15, 1973, 78; Neil Brown and Bonny Levy, "Black Group Pickets City School Offices," (New Brunswick, NJ) Home News, Oct. 15, 1973, 1." ${ }^{100}$ Jermaine Elkins, "North Brunswick Seeks Ruling Changes," (New Brunswick, NJ) Home News, Oct. 17, 1973, 1.

${ }^{101}$ Brown and Levy, "Black Group Pickets City School Offices;" Johnston, "Blacks Plan Boycott Today of New Brunswick School," New York Times, Oct. 15, 1973, 78; Johnston, "Blacks Stay Out in New Brunswick," New York Times, Oct. 16, 1973, 91; "School Boycott Over," (New Brunswick, NJ) Home News, Oct. 16, 1973, 1; Ann Ledesma, "Emotions Rampant at a City School Board Session," (New Brunswick, NJ) Home News, Oct. 17, 1973, 1; and "New Brunswick H.S. Boycott Meets Success," Black Voice, Nov. 6, 1973, 9.

${ }^{102}$ Ronald Sullivan, "Busing Becomes a Campaign Issue," New York Times, Sept. 20, 1973, 99; Sullivan, "Sandman Backs a Referendum on Busing," New York Times, Oct. 9, 1973, 98; and Mihalenko, North Brunswick, 36-38.

${ }^{103}$ Janson, "Arbiter Backs Transfers from New Brunswick High;" "Fear Expressed on School Ruling;" and Richard J. H. Johnston, "North Brunswick Dedicates School," New York Times, Oct. 29, 1973, 74. 
On November 30, the Department of Education's acting commissioner, Edward Kilpatrick, adopted examiner Greenwood's recommendations, with one significant difference: he approved the immediate transfer of all tenth graders from New Brunswick High School to North Brunswick High. Kilpatrick's decision seemed to please no one. Black and white residents of New Brunswick, who had often disagreed over the city's schools, united to oppose this apparent step toward consolidating the high schools, and black parents called on the acting commissioner to "permit communities to educate their own students." White parents in North Brunswick objected to Kilpatrick's decision to bus the tenth graders to their school. ${ }^{104}$ North Brunswick continued to press its case for local control, battling the New Brunswick Board of Education and the state government. In March 1974, the North Brunswick Board of Education audaciously announced that it would no longer pay tuition to send students to New Brunswick and declared that all high school students from North Brunswick would attend North Brunswick High in the fall. The Department of Education sternly informed the board that it had no authority to withdraw its students from New Brunswick High without the state's approval. ${ }^{105}$

Years of legal wrangling over consolidation culminated in hearings before the Department of Education in the summer and fall of 1974. Despite intense rancor between the Brunswicks, the New Brunswick Board of Education argued implausibly that the city and the adjacent suburb were effectively "one community," and so should operate a single school district. The New Brunswick board advocated implementing regionalization or consolidation and busing, without which, it warned, New Jersey would become "an apartheid society; the cities will be black and the suburbs will be white." ${ }^{106}$ But white residents of North Brunswick and black residents of New Brunswick opposed consolidation and supported local control, citing the US Supreme Court's recent ruling in Milliken v. Bradley, which declared busing children from one school district to another an impermissible remedy for de facto school segregation. ${ }^{107}$ North Brunswick residents

104 "North Brunswick School Will Get Black Students," New York Times, Dec. 1, 1973, 70; and "North Brunswick to Appeal Order," New York Times, Dec. 3, 1973, 82. Black parents quoted in Richard J. H. Johnston, "Coalition Fights School Transfer," New York Times, Dec. 12, 1973, 99.

${ }^{105}$ Richard J. H. Johnston, "North Brunswick Moves on Busing," New York Times, March 4, 1974, 62; "Pupil Shift Barred in North Brunswick," New York Times, March 21, 1974, 86; and "School-Sharing Order Retained," New York Times, May 30, 1974, 78.

${ }^{106}$ New Brunswick v. North Brunswick and Milltown (1974), 966.

${ }^{107}$ Alfonso A. Narvaez, "Burke Issues Interim Plan for Brunswicks' Schools," New York Times, Aug. 17, 1974, 56; "School Plan Fought by North Brunswick," 
contended that no educational research had demonstrated conclusively that integration benefited students and stated that "little, if any benefit would flow from mixing the races in an atmosphere of hostility." Jack Borrus, attorney for the North Brunswick Board of Education, pointed out that whites in New Brunswick had effectively rejected their local public schools, estimating that at least three thousand of the city's white students (in all grades) now attended private schools. North Brunswick called black witnesses from New Brunswick who also opposed regionalization or outright consolidation and espoused community control, stating that "their goal and obligation is to cater to the needs of their own black pupils and that any sharing of this responsibility with neighboring white municipalities would only further dilute and frustrate this prime objective."108

In August 1974, only three weeks before the start of the school year, Commissioner of Education Fred G. Burke issued an interim order permitting all students from North Brunswick to attend high school in their hometown during the upcoming year. ${ }^{109}$ North Brunswick residents cheered Burke's decision, but Frank Totten, president of the New Brunswick Teachers Association, castigated it for leaving both school districts segregated and "in a position just like the South was in."110 The New Brunswick Board of Education vowed to continue its battle for consolidation, but the Home News, which had previously supported regionalization and integration, now urged the board to drop its suit against North Brunswick. ${ }^{11}$ In October, Commissioner Burke permanently terminated the sendingreceiving relationship between the school districts. Burke wearily observed that the "tortuous process" of adjudicating the dispute

New York Times, Aug. 20, 1974, 76; New Brunswick v. North Brunswick and Milltown, (1974), 962-99; and Milliken v. Bradley, 418 U.S. 717 (1974). On Milliken v. Bradley, see Joyce A. Baugh, The Detroit School Busing Case: Milliken v. Bradley and the Controversy over Desegregation (Lawrence: University Press of Kansas, 2011); Eleanor P. Wolf, Trial and Error: The Detroit School Segregation Case (Detroit: Wayne State University Press, 1981); and Formisano, Boston Against Busing, 12, 229.

${ }^{108}$ New Brunswick v. North Brunswick and Millown (1974), 967. See also Bonny Levy, "North Brunswick Asks School Suit Dismissal," (New Brunswick, NJ) Home News, Aug. 20, 1974, 1.

${ }^{109}$ New Brunswick v. North Brunswick and Milltown (1974), 961-62. See also Alvin King and Bonny Levy, "Burke's Decision Ends a Long Tradition," (New Brunswick, NJ) Home News, Aug. 17, 1974, 1.

110 "City Teachers Reject Student Shift," (New Brunswick, NJ) Home News, Aug. 21, 1974, 1; and Robert Windrem, "City Hopes Township Kids Stay," (New Brunswick, NJ) Home News, Aug. 20, 1974, 1.

111 "Let's Get On with Education," (New Brunswick, NJ) Home News, Aug. 18, 1974, D2; Charles Johnson, "It's Time to Get Off the Regionalization Treadmill," (New Brunswick, NJ) Home News, Aug. 22, 1974, 31. 
between the Brunswicks had dragged on for three years. He declared that he "abhors the existence of a segregated society," but admitted that the state's effort to foster racial integration had failed and that mandating consolidation and busing could not bridge the chasm dividing the Brunswicks. Burke accepted North Brunswick's claim that New Brunswick High had been plagued by trouble and overcrowding. In an effort to maintain some measure of racial integration, he ordered North Brunswick High to offer enrollment to upwards of two hundred New Brunswick students, if they volunteered to attend the suburban high school. He also denied the all-white community of Milltown permission to send its students to North Brunswick High, which would decrease New Brunswick High's white enrollment even further. Many residents of Milltown responded by withdrawing their children from New Brunswick High: only 18 percent of high school students from Milltown enrolled in New Brunswick High in the 1974-1975 school year. Despite the animosity between the Brunswicks, Burke urged the two districts to cooperate "to ameliorate the negative effects of racial segregation" and "to make a reality of their mutually espoused concern for racial harmony." 112

The departure of seven hundred white students made New Brunswick High a majority-minority school: when classes began in fall 1974, 60 percent of New Brunswick High's students were black or Latino, and white parents increasingly opted to enroll their children in private schools or moved elsewhere. The high school's new demographics did not eliminate racial tensions, as violence broke out in October, resulting in injuries to ten students and three arrests for assault and weapons possession. ${ }^{113}$ The 1974 mayoral campaign also stoked racial tension in New Brunswick throughout the fall. When Governor Byrne appointed Mayor Sheehan as New Jersey's commissioner of community affairs in 1973, Aldrage B. Cooper Jr., the city's first black commissioner, was appointed to fill her unexpired term. ${ }^{114}$ Cooper ran for mayor in 1974, but lost a hotly contested campaign against attorney Richard Mulligan. ${ }^{115}$ At the time, Cooper diplomatically declined to blame racism for the election's outcome; decades

${ }^{112}$ New Brunswick v. North Brunswick and Milltown (1974), 996-98; 998.

${ }^{113}$ On the opening of North Brunswick High School, see Bonny Levy, "High Schools Offer Contrasts," (New Brunswick, NJ) Home News Sept. 5, 1974, 6; and Richard J. H. Johnston, "New Brunswick Seeks Racial Peace in High School," New York Times, Oct. 27, 1974, 78.

114 "New Brunswick's New Black Mayor Takes His Post," New York Times, Feb. 20, 1974, 78 .

${ }^{115}$ Ted Serrill, "Mulligan Is Next Mayor," (New Brunswick, NJ) Home News, Nov. 6, 1974, 1; and "City Voters Give Mulligan a Mandate," (New Brunswick, NJ) Home News, Nov. 6, 1974, 30. 
later, he acknowledged that some whites felt that the city government had been too conciliatory to blacks' demands and disliked having a black mayor. ${ }^{116}$ Some whites also vented their antagonism to Superintendent Durant, vandalizing his home and car in May 1975, defacing them with racist slurs, including "Get out nigger" and "The KKK was here." 117 Shortly after the school year began in September, Durant abruptly resigned, accusing Mayor Mulligan of "harassment ... political interference ... and racism." More than two-thirds of New Brunswick High's black students walked out of classes to protest Durant's departure. ${ }^{118}$

Geographically adjacent, the Brunswicks had gone their separate ways. In the spring of 1976, the New Brunswick Board of Education withdrew its proposal to maintain a relationship between the New Brunswick and North Brunswick schools. Later that year, the state's Department of Education terminated the agreement that allowed some New Brunswick students to attend North Brunswick High. The department contended that New Brunswick, unlike many other cities, was not principally a victim of "white flight," because whites remained a majority of the city's residents. Nonetheless, the schools had experienced white flight of a sort, as many white parents chose to pay tuition to send their children to private schools instead of New Brunswick High. Ultimately, the department frankly conceded that its effort to create racially integrated schools in the Brunswicks had proved "dramatically unsuccessful." 119

\section{The Brunswick Blues}

In 1976, journalist and activist Gene Robinson summed up the past decade of New Brunswick's history in the Black Voice and diagnosed

${ }^{116}$ Aldrage B. Cooper Jr., interview with author, Feb. 9, 2010.

117 “School Aide Finds Home Vandalized," New York Times, May 19, 1975, 63.

118 “Top School Post Remains an Issue," New York Times, Sept. 29, 1975, 67; and Sandee Gregg, "Durant Resigns; 70\% NB Students Boycott," Black Voice-Carta Boricua, Sept. 23, 1975, 1.

${ }^{119}$ Thirty-four New Brunswick students attended North Brunswick High in the 1975-1976 school year; fifty-nine enrolled in 1976-1977. In 1974 and again in 1975, the New Jersey Department of Education denied Milltown permission to send its high school students to North Brunswick High. Residents of Milltown continued to withdraw their children from New Brunswick High. In 1977, the department permitted Milltown to establish a sending-receiving relationship with Spotswood, another nearly all-white community. In the Matter of the Board of Education of Milltown (1976) in New Jersey School Law Decisions (Trenton, NJ: Department of Education, n.d.) 858-59, 862; and In the Matter of the Board of Education of Milltown (1977) in New Jersey School Law Decisions (Trenton, NJ: Department of Education, $n$. d.), 207-208. 
black residents as suffering from "a severe case of the 'Brunswick Blues." The civil rights era had come and gone, and black people had not gained their rightful share of power. Al Cooper, the city's first black commissioner and mayor, was out of office. Neighborhood House, a center for black activism, had closed. Efforts to gain significant influence over the public schools and improve education for minority students had made little progress. ${ }^{120}$

The struggle between New Brunswick and North Brunswick resulted not from a disembodied process of suburbanization, white flight, or deindustrialization, but from a contingent debate over the future of the communities and their schools. White residents of North Brunswick, eager to develop their rapidly growing suburb and troubled by racial conflict in New Brunswick High School, invoked local control to justify their determination to build their own high school and to sever their relationship with New Brunswick High. Black and Latino residents of New Brunswick initially sought to maintain integration but soon became supporters of community control in an effort to gain more influence over the public schools and improve education for minority students. School administrators and many white residents of New Brunswick, concerned about the future of the school system and their city, generally supported integration. Education officials in the state of New Jersey voiced emphatic support for school integration but proved unwilling to enforce it in the face of considerable political pressure from both white suburbanites and black city residents. Ironically, in the "era of integration," in which both the state and federal governments ostensibly supported school integration, as did many New Brunswick residents and school administrators, New Brunswick High, formerly an integrated school, became majority-minority. As some residents had foreseen, white enrollment subsequently decreased until the school enrolled almost exclusively minority students, as it does today. ${ }^{121}$

${ }^{120}$ Gene Robinson, "Brunswick Blues," Black Voice-Carta Boricua, April 2, 1976, 1. On Robinson, see McCormick, Black Student Protest Movement, 18-19.

${ }^{121}$ As many black residents had predicted, when New Brunswick High School became majority-minority, white parents increasingly withdrew their children from it. Today, 84.7 percent of the school's students are Latino and 13.7 percent are black. Data on the New Brunswick and North Brunswick schools is available online from the New Jersey Department of Education, http://www.state.nj.us/education/pr/1314/23/233530050.pdf. In its 1990 decision in Abbott v. Burke (Abbott II), the New Jersey Supreme Court ruled that New Jersey's overwhelming reliance on local property taxes to fund public education violated the state constitution's guarantee of a "thorough and efficient system" of public education for all students, because schools in poorer communities lacked sufficient resources. Abbott v. Burke 119 N.J. 287 (1990). The New Brunswick Public Schools are one of New Jersey's thirty-one 
More than six decades after Brown and four decades after the battle of the Brunswicks, Molly Townes O'Brien's assessment is, unfortunately, apt: "America's schools remain substantially segregated and unequal." 122

"Abbott districts," which receive additional funding from the state in an effort to redress the problems confronted by poorer school districts.

${ }^{122}$ Molly Townes O'Brien, "Desegregation and the Struggle for Equal Schooling: Rolling the Rock of Sisyphus," in Our Promise: Achieving Educational Equality for America's Children, ed. Maurice R. Dyson and Daniel B. Weddie (Durham, NC: Carolina Academic Press, 2009), 23; see also Greason, Suburban Erasure, 1, 187. On the shortcomings of recent efforts to reform urban schools, see Mary Pattillo, Black on the Block: The Politics of Race and Class in the City (Chicago: University of Chicago Press, 2007), 177-79. For a detailed analysis of school segregation in New Jersey, see Greg Flaxman et al., A Status Quo of Segregation: Racial and Economic Imbalance in New Jersey Schools, 1989-2010 (Los Angeles: Civil Rights Project, Series on Segregation in East Coast Schools, October 2013), https://www.civilrightsproject. ucla.edu/research/k-12-education/integration-and-diversity/a-status-quo-of-segregation-racial-and-economic-imbalance-in-new-jersey-schools-1989-2010. 